\title{
KEBIJAKAN MANAJEMEN DAN REAKSI CUSTOMER TERHADAP PENERAPAN GREEN HOTEL (Studi Kasus pada Harris Hotel \& Conventions di Kota Malang)
}

\author{
Lily Harlina Putri ${ }^{1}$, Suharyono ${ }^{2}$, Edriana Pangestuti ${ }^{3}$ \\ Fakultas Ilmu Administrasi, Universitas Brawijaya, Malang, Indonesia ${ }^{123}$ \\ Email: lilyharlinaputri@yahoo.com¹, sharyonofia@ub.ac.id ${ }^{2}$, edriana_fia@ub.ac.id ${ }^{3}$
}

\begin{abstract}
This research is intended to indetify the reason of management for applying green hotels concept, to describe policy of management related green hotels, to analyse the obstacle that will face, to know well positive impact that will get and to explore customer reaction regarding green hotels implementation in Harris Hotels \& Conventions. The researcher use describtions methode with qualitative approach, also use primary data and secondary data that was collected by observation technique, interview, and documentation. This interview was conducted to 5 persons from hotels management and 15 persons from customer. The result of this research show that The Haris Hotels implement green concept due to goverment regulation and desire to do continues environment fundamental. Harris Hotel \& Conventions Malang make some policy base on building side, efficiency of energy, product selection and waste management which follow standart of Green Hotels concept, except policy of water efficiency that not yet reach maximum result. There are 5 obstacles that will face and 2 positive impact that will get from green hotel concept implementation. Beside, customer reaction tend to support if Harris Hotels \& Conventions Malang become green hotels.
\end{abstract}

Keywords:Management Policy, Customer Reaction, Green Hotel

\begin{abstract}
ABSTRAK
Penelitian ini bertujuan untuk mengidentifikasi alasan manajemen menerapkan Green Hotel, mendeskripsikan kebijakan-kebijakan manajemen terkait Green Hotel, menganalisis hambatan yang dihadapi, mengetahui hal positif yang didapatkan, dan mengeksplorasi reaksi customers terhadap penerapan Green Hotel di Harris Hotel \& Conventions. Peneliti menggunakan metode deskriptif dengan pendekatan kualitatif, serta menggunakan data primer dan sekunder yang dikumpulkan dengan teknik observasi, wawancara dan dokumentasi. Dilakukan wawancara dengan 5 orang dari pihak manajemen dan 15 customers hotel. Hasil penelitian menunjukkan bahwa Harris menjalankan konsep green karena aturan dari pemerintah dan keinginan menjalankan pripsip lingkungan berkelanjutan. Harris Hotel \& Conventions Malang mebuat kebijakan dari segi bangunan, efisiensi energi, pemilihan produk, dan pengelolaan limbah sesuai standar konsep Green Hotel, kecuali untuk kebijakan efisiensi air yang belum maksimal. Ada 5 hambatan yang dihadapi dan 2 hal positif yang didapatkan dari penerapan konsep green hotel. Selain itu, reaksi customer cenderung mendukung jika Harris Hotel \& Conventions Malang menjadi green hotel.
\end{abstract}

Kata kunci: Kebijakan Manajemen, Reaksi Customer, Green Hotel 


\section{PENDAHULUAN}

Sejak tahun 2010, Indonesia sudah didesak oleh Wisata MICE (Meeting, Intensive, Conference, Exhibition) dan WTO (World Tourism Organization) untuk menerapkan Green Tourism atau pariwisata berbasis dan berwawasan lingkungan (Kabar Bisnis, 2010). Hal ini disebabkan oleh isu kerusakan lingkungan dan pemanasan global yang sudah mendunia. Dalam rangka pembangunan industri pariwisata Indonesia, dimana masuk dalam RPJM (Rencana Pembangunan Jangka Menengah) 2015-2019, membuat banyak hotel diajak untuk mendukung kegiatan Green Hotel. Dengan banyaknya pembangunan hotel, maka akan berpotensi terhadap kerusakan lingkungan akibat pemanfaatan banyak sumber daya (Anggita, Wardhani, \& Danusastro, 2016). Gerakan ini menjadi salah satu langkah yang dapat dilakukan untuk meminimalisir kerusakan lingkungan dari sektor bangunan hotel yang pertumbuhannya meningkat dari waktu ke waktu.

Kementerian Pariwisata kemudian menerapkan standar dan kriteria berwawasan lingkungan guna mendorong pengelola hotel agar memiliki sikap dan tindak untuk melindungi, membina lingkungan hidup, serta meningkatkan pengelolaan yang berkelanjutan dan berwawasan lingkungan (Kementerian Pariwisata Republik Indonesia, 2016). Standar yang dibuat meliputi manajemen hotel, tata guna lahan, konsep bangunan, penggunaan material bangunan dan produk lokal yang ramah lingkungan, efisiensi energi, konservasi air, dan pengelolaan limbah (Kementerian Pariwisata Republik Indonesia, 2016).

Gerakan Green Hotel mendapat dukungan dari pemerintah pusat salah satunya adalah Kementerian Pariwisata dan Ekonomi Kreatif melalui event Penganugerahan Green Hotel Award yang diselenggarakan setiap dua tahun sekali sejak tahun 2009. Berdasarkan data penerima penghargaan Green Hotel Award tahun 2011-2019, belum ada hotel yang memperoleh penghargaan Green Hotel di Kota Malang. Padahal Kota Malang memiliki potensi lebih untuk diterapkannya gerakan tersebut karena didukung oleh lingkungan dengan suhu udara yang terbilang dingin sehingga dapat lebih mudah dalam menghemat energi, dan Malang memiliki air tanah yang masih bagus juga berlimpah, sehingga peran manajemen hotel sangat penting untuk pelaksanaan dan keberhasilan program Green Hotel.

Menurut "Travellers Choice Pemenang 2018" TripAdvisor Indonesia, Harris Hotel \& Conventions merupakan hotel yang menempati posisi urutan ke 2 dari 59 hotel di Malang (terdiri dari Bintang 1-5) dengan ulasan tertinggi yaitu sebanyak 1.162 ulasan. Berdasarkan minat yang tinggi dari customers, menarik perhatian peneliti untuk memilih Harris Hotel \& Conventions sebagai salah satu perwakilan hotel berbintang di Kota Malang. Harris Hotel \& Conventions adalah salah satu hotel bintang empat di Kota Malang. Berada di lokasi yang strategis, tidak terlalu jauh dari pusat kota namun jauh dari bising kepadatan kota dan jauh dari polusi. Berdasarkan observasi awal peneliti, Harris Hotel \& Conventions Malang sudah mengarah pada Konsep Green Hotel atau hotel ramah lingkungan meskipun belum menjalankannya $100 \%$ sesuai dengan ketentuan yang dibuat oleh pemerintah.

Aspek manajemen hotel berwawasan lingkungan dirasa sangat penting untuk diterapkan pada sebuah hotel (Ferianto, Darsiharjo, \& Rahmafitria, 2014). Dengan dibuatnya kebijakan manajemen berwawasan lingkungan, hotel akan digerakkan dari banyak aspek menuju hotel yang green, sesuai dengan kebijakan yang ditentukan pemerintah. Namun sebagian perusahaan melakukan kegiatan green hanya untuk memenuhi peraturan pemerintah terkait lingkungan agar terhindar dari hukuman (McDaniel \& Rylander, 1993). Dalam pelaksanaanya pada setiap hotel mungkin berbeda-beda, tergantung dari kebijakan pihak manajemen dari masing-masing hotel. Tidak semua manajer berkeyakinan sama dan sependapat untuk mendukung Green Hotel (Chan, 2013). Manajer hotel umumnya mempertanyakan apakah produk lingkungan, jasa, serta kinerja mereka benar-benar dapat mempengaruhi kunjungan pelanggan. Hal tersebut yang mungkin menjadi alasan mengapa belum semua hotel menerapkan Green Hotel, termasuk Harris Hotel \& Conventions Malang.

Customer juga memiliki peran untuk menyukseskan program Green Hotel, seperti kesadaran mereka untuk memilih hotel yang ramah lingkungan dan mengikuti program Green Hotel yang diterapkan pada hotel tersebut. Dalam 
penelitian Sinangjoyo, didapati bahwa masih kurangnya tingkat kesadaran tamu hotel untuk mengkonsumsi produk ramah lingkungan (Sinangjoyo, 2013). Para tamu hotel yang sadar akan pentingnya ramah lingkungan cenderung bersedia membayar dengan harga yang lebih mahal untuk menginap dihotel tersebut karena mereka sadar bahwa produk hijau memang lebih mahal dari pada produk-produk yang tidak ramah lingkungan (Desliana, Gaffar, \& Andari, 2014). Para tamu hotel tidak hanya berani membayar mahal, tetapi juga sukarela untuk ikut serta mendukung kebijakan-kebijakan ramah lingkungan yang dibuat oleh hotel. Dalam penelitian Lee, Jai and $\mathrm{Li}$, didapati bahwa sebagian tamu merespons positif terhadap praktik hijau ketika mereka memahami pentingnya menjaga lingkungan, mereka berkenan mengurangi penggunaan energi atau penghematan air, namun terdapat sebagian tamu lainnya yang merasa tidak nyaman selama masa inap mereka karena kurangnya pemahaman tentang praktik Green Hotel (Lee, Jai, \& Li, 2016). Hal ini ditunjukkan dengan sikap tamu yang tidak menghendaki adanya pembatasan fasilitas, pembatasan sumber daya, penentuan area dan sistem larangan (Sinangjoyo, 2013).

Dapat disimpulkan bahwa masih ditemui adanya pro dan kontra baik dari pihak manajemen hotel maupun customer hotel terhadap gerakan Green Hotel. Latar belakang tersebut yang menjadi dasar bagi peneliti untuk mengangkat judul "Kebijakan Manajemen tentang Penerapan Green Hotel dan Reaksi Customers (Studi Kasus pada Harris Hotel \& Conventions di Kota Malang)".

\section{KAJIAN PUSTAKA Hotel}

Hotel merupakan salah satu jenis akomodasi dalam wujud kamar dengan jumlah banyak di dalam satu bangunan yang disewakan secara harian, dilengkapi dengan jasa pelayanan, terdapat fasilitas hiburan, makanan dan minuman (Badan Pusat Statistik Kota Malang, 2017). Dalam penelitian ini peneliti memfokuskan pada Resort Hotel, yaitu hotel yang berlokasi jauh diluar kota dan para tamu kebanyakan wisatawan yang memang bertujuan untuk berekreasi (Arjana, 2016). Berdasarkan lokasi pada wilayah topografis tertentu, resort hotel digolongkan menjadi beberapa jenis, diantaranya Beach hotel, Cliff hotel, Mountain hotel, Lake hotel, Ravine hotel (Arjana, 2016).

\section{Green Marketing}

Green Marketing didefinisikan sebagai berbagai aktivitas yang didesain untuk menghasilkan dan memfasilitasi setiap perubahan yang bertujuan untuk memenuhi kebutuhan dan keinginan manusia, dengan meminimalkan dampak perusakan pada lingkungan alam (Polonsky, 1994). Hal ini dikarenakan dalam pemenuhan kebutuhan dan keinginan manusia, terdapat potensi untuk menimbulkan dampak negatif pada lingkungan alam. Dalam green marketing terdapat beberapa komponen (Wu \& Chen, 2014), seperti:

1. Green customers

2. Green production process

3. Green financial affairs

4. Reasons of being green

\section{Konsep Green Hotel}

Konsep green hotel adalah salah satu pengembangan dan pengelolaan hotel yang berkelanjutan dengan pemahaman bangunan yang ramah lingkungan yang berperan penting dalam mitigasi GRK (Gas Rumah Kaca) dengan upaya konservasi dan efisiensi energi dan air yang meliputi aspek manajemen hotel berwawasan lingkungan, operasional hotel berwawasan lingkungan, tata guna lahan, efisiensi penggunaan material bangunan, efisiensi air, efisiensi energi, kualitas pengudaraan, dan pengelolaan limbah (Kementerian Pariwisata Republik Indonesia, 2016). Setiap hotel diharapkan mengevaluasi terlebih dahulu seperti dari kondisi ekologi sebelum memulai konstruksi dan mencoba untuk tidak memperburuk dampak terhadap lingkungan (Erdogan \& Baris, 2007). Sehingga lingkungan tidak akan terpengaruh ketika mengembangkan industri pariwisata. Hal ini disebabkan tujuan dari green hotel yaitu untuk memperkenalkan ide perlindungan lingkungan ke dalam hotel baik pada orang-orang yang memberikan layanan dan proses operasional atau mengacu pada fasilitas utama dan konstruksi untuk menghemat energi dan mengurangi limbah (Chen \& Chen, 2012).

Yang termasuk dalam orientasi dasar dalam green hotel (Holcomb, Upchurch, \& Okumus, 2007), diantaranya: 
1) Ketika merancang sebuah konstruksi, semua harus mempertimbangkan bahan yang digunakan, efek radiasi dan pembuangan atau daur ulang dari bahanbahan yang digunakan.

2) Ada ketentuan dalam memilah sampah didaur ulang, seperti kertas, botol-botol (botol kaca aluminium, botol besi, dan botol plastik), dan untuk bahan yang mengandung polusi (baterai, lampu, kartrid), bisa diambil oleh perusahaan daur ulang dengan bidang khususnya masing-masing yang telah dikontrak oleh perusahaan.

3) Green hotel perlu mempromosikan ide mengenai perlindungan terhadap lingkungan sebagai bentuk meminimalisir polusi melalui perencanaan sistem daur ulang, dan pemanfaatan energi surya, energi angin, energi biomassa, dan tenaga hidrolik.

4) Pemerintah diharapkan dapat mengalokasikan dana atau membebaskan pajak untuk mendorong hotel dalam penghematan air dan energi, juga memperbaiki prosedur layanan atau menambahkan ide tentang perlindungan lingkungan pada kursus pelatihan. Hal ini dapat mengurangi keraguan manajer hotel tentang penerapan kebijakan green.

\section{Reaksi Konsumen}

Reaksi konsumen pada setiap hal (produk, jasa, program, aturan, fasilitas,dll), terlebih pada yang akan melibatkan dirinya dapat berbeda-beda, tergantung pada persepsi dan harapan dari masing-masing individu akan hal itu. Hal tersebut dikarenakan adanya perilaku konsumen yang beragam. Perilaku konsumen yaitu ketika konsumen dalam mencari, membeli, menggunakan, mengevaluasi lalu menghabiskan suatu produk yang kemudian diharapkan dapat memuaskan kebutuhan mereka (Schiffman \& Kanuk, 2008). Hal serupa juga dikatakan oleh Nitisusastro, bahwa perilaku konsumen adalah tahapan atau langkah yang ditempuh oleh individu atau kelompok untuk memenuhi kebutuhan dan keinginan mereka (Nitisusastro, 2013).

Setiap individu akan bertindak dan bereaksi berdasarkan persepsi masing-masing individu (Schiffman \& Kanuk, 2008). Persepsi bisa disebut juga dengan anggapan dari kualitas yang dirasakan. Hal lain yang dapat mempengaruhi perilaku konsumen adalah harapan, motif, dan pengetahuan yang didasari oleh pengalaman sebelumnya (Schiffman \& Kanuk, 2008).

\section{Kebijakan Manajemen}

Dalam industry pariwisata, hotel memiliki peranan penting dalam meminimalisir kerusakan lingkungan (Kementerian Pariwisata Republik Indonesia, 2016), sehingga dibutuhkan Manajemen hijau pada hotel melalui program Green Hotel. Terdapat lima aspek dari manajemen dalam membangun dan mengelola green hotel (Chen \& Chen, 2012), yaitu:

1) Pembelian Produk Green.

2) Kebijakan Lingkungan.

3) Manajemen Hotel.

4) Pendidikan Karyawan.

5) Pendidikan Konsumen.

\section{METODE PENELITIAN}

Penelitian ini bersifat deskriptif dengan pendekatan kualitatif. Lokasi dalam penelitian ini adalah Harris Hotel \& Conventions Malang. Dilakukan wawancara dengan lima orang narasumber dari pihak manajemen hotel (Human Resource Manager, Chief Engineer, Asisten Chief Engineer, Chef Manajer, dan salah satu Resepsionis hotel) dan lima belas orang narasumber yang merupakan customer Harris Hotel \& Conventions Malang. Informan dipilih menggunakan teknik purposive sampling. Dokumen, berita, dan data statistik juga digunakan untuk melengkapi data penelitian sebagai data sekunder. Data dianalisis melalui empat tahap mulai dari pengumpulan informasi, reduksi data, penyajian data, kemudian penarikan kesimpulan dan verifikasi, sesuai dengan model interaktif analisis data Miles dan Huberman (1992:20). Keabsahan data dilakukan dengan menggunakan triangulasi sumber (data).

Berikut yang menjadi fokus dalam penelitian ini:

1. Hal yang melatarbelakangi Harris Hotel \& Conventions menerapkan Green Hotel

2. Kebijakan manajemen terkait konsep Green Hotel yang diterapkan Harris Hotel \& Conventions 
3. Hambatan yang dihadapi manajemen Harris Hotel \& Conventions dalam menerapkan konsep Green Hotel

4. Hal positif yang diperoleh dari penerapan konsep Green Hotel pada Harris Hotel \& Conventions?

5. Reaksi customers terhadap penerapan konsep Green Hotel yang diterapkan Harris Hotel \& Conventions

\section{HASIL DAN PEMBAHASAN}

Alasan Harris Hotel \& Convention mulai mengarah pada Green Hotel

Alasan Harris Hotel \& Conventions Malang mulai mengarah pada green hotel cenderung untuk mematuhi aturan dari pemerintah terkait Perlindungan dan Pengelolaan Lingkungan Hidup, walaupun dari manajemen Tauzia juga ingin menjalankan prinsip pengelolaan lingkungan berkelanjutan. Ini sejalan dengan McDaniel dan Rylander (1993) bahwa sebagian perusahaan melakukan kegiatan green hanya untuk memenuhi peraturan pemerintah terkait lingkungan agar terhindar dari hukuman. Belum ada target dari owner Harris Hotel \& Conventions Malang untuk melabelkan hotelnya menjadi Green Hotel, sehingga belum ada upaya lebih untuk memaksimalkan Harris menjadi $100 \%$ menjalankan dan memiliki sertifikat Green Hotel. Yang menjadi target utama Harris Hotel saat ini adalah guest satisfaction. Pihak manajemen tidak merasa bahwa memiliki sertifikat Green Hotel dapat meningkatkan kunjungan customers. Sejalan dengan Robinot dan Giannelloni, dari hasil penelitiannya penambahan atribut "green" tidak berkontribusi untuk membentuk kepuasan pelanggan (Robinot \& Giannelloni, 2010). Para customer tampaknya tidak menentukan pilihan menginap untuk produk green hotel. Terlebih di Malang belum ada satu hotel pun yang berlabel Green Hotel, sehingga belum ada persaingan dibidang tersebut yang membuat Harris Hotel \& Conventions Malang merasa belum perlu menjadi green hotel. Padahal dengan mengawali menjadi green hotel memiliki peluang lebih besar karena tidak banyak hotel yang secara serius menekankan aspek lingkungan. Hotel yang lebih dulu merenapkan strategi ramah lingkungan bisa mencapai keunggulan kompetitif (Setiyaningrum, Udaya, \& Efendi, 2015).
Kebijakan-kebijakan manajemen terkait gerakan Green Hotel yang diterapkan pada Harris Hotel \& Conventions

Harris Hotel \& Conventions Malang mebuat kebijakan dari segi bangunan, efisiensi energi, pemilihan produk, dan pengelolaan limbah telah memenuhi standar konsep Green Hotel, kecuali kebijakan dalam efisiensi air.yang belum maksimal.

1. Bangunan

Pemilihan lokasi Harris Hotel \& Conventions Malang ditempatkan jauh dari sumber polusi dan kebisingan aktifitas kendaraan karena letaknya jauh dari jalan raya. Letak bangunan Harris Hotel sudah terhindar dari pencemaran biologis, kimia dan lokasi negatif lainnya sehingga tidak akan berbahaya bagi bangunan maupun penghuni didalamnya. Dibangun gedung dengan bentuk $L$ dengan Sistem Dilatasi Bangunan untuk menghindari kerusakan atau retak pada bangunan yang ditimbulkan oleh gaya fertikal dan horizontal seperti pergeseran tanah, gempa bumi, dan lain sebagainya. Harris Hotel \& Conventions Malang dikelilingi oleh lahan terbuka hijau. Didesain memiliki banyak jendela dan ruang terbuka guna mendapat pencahayaan alami dan sirkulasi udara yang baik. Disetiap koridor terdapat jendela besar sehingga pada siang hari dapat meminimalisir penyalaan lampu dan penggunaan AC.

Pada taman dibuat lubang-lubang biopori untuk memperbesar pola resapan air kedalam tanah saat terjadi hujan sehingga dapat mengurangi resiko banjir. Terdapat juga STP (Sewage Treatment Plant) yang merupakan bangunan instalasi sistem pengelolaan limbah rumah tangga atau limbah cair domestik termasuk limbah dari dapur, air bekas, air kotor, dan kotoran dari WC kamar mandi. Dibuat ruangruang khusus untuk menjadi TPS sementara dari limbah B3 dan sampah hotel lainnya.

Harris menggunakan bahan-bahan bangunan yang ramah lingkungan, tidak mudah lapuk, roof menggunakan bahan yang anti terbakar dan untuk bangunan menggunakan bahan-bahan ringan untuk antisipasi goncangan dari gempa. Yang termasuk dalam orientasi dasar dalam green hotel, ketika merancang sebuah konstruksi, semua harus mempertimbangkan material, efek radiasi dan pembuangan atau daur 
ulang dari bahan-bahan yang digunakan (Holcomb, Upchurch, \& Okumus, 2007). Pencahayaan gedung adalah yang terpenting. Dapat dilihat bahwa dari poin-poin yang disebutkan oleh Kementrian Pariwisata Republik Indonesia terkait apasaja yang perlu dilakukan, Harris Hotel \& Conventions Malang telah memenuhi kualifikasi Green Hotel dari segi bangunan.

\section{Energi}

Harris Hotel \& Conventions Malang memiliki kebijakan dalam penggunaan energi agar bisa sehemat mungkin. Sebelum Hotel Harris dibangun, pihak manajemen sudah menentukan mulai dari tipe pendingin udara, tipe generator untuk pembangkit listrik yang digunakan, tipe penghasil hot water yang digunakan, tipe peralatan kitchen, tipe peralatan yang ada dikamar dan termasuk tipe peralatan yang digunakan di public area atau disekitar hotel seperti lampu-lampu, pompa-pompa yang terdiri dari pompa hydrant, pompa kolam renang, booster pump untuk mompa air dingin dan panas keseluruh hotel, semua yang ditentukan adalah tipe ramah lingkungan dengan konsumsi energi yang rendah.

Harris Hotel \& Conventions Malang telah menggunakan teknologi hemat energi dan juga ramah lingkungan. Harris memanfaatkan chiller untuk mendinginkan ruang. Selain untuk mendinginkan ruang, chiller juga dimanfaatkan sebagai pembuat air panas yang akan dialirkan pada setiap kamar mandi hotel, tidak lagi menggunakan gas LPG atau pun solar. Dari segi sistem pencahayaan buatan, Harris Hotel mulai menggunakan teknologi hemat energi seperti menggunakan lampu jenis LED (Light Emitted Diode). Harris Hotel \& Conventions Malang telah mengunakan sistem kontrol otomatis pada setiap kamar hotel berupa Energy Saving Switch atau biasa disebut Saklar Kartu yang didesain untuk menghidupkan listrik dalam kamar dengan memasukan key card hotel didalamnya dengan tujuan untuk menghemat energi listrik. Sistem kontrol otomatis lainnya adalah penggunaan timer dan sensor matahari pada lampu-lampu ditaman, koridor dan jalan umum sehingga saat gelap atau malam akan secara otomatis menyala dan pagi jam 5 atau saat mulai terang lampulampu akan mati. Harris menerapkan aturan dalam penggunaan lift khusus untuk karyawan, yaitu bagi karyawan yang hanya menaiki 2 lantai dan menuruni 2 lantai diharapkan menggunakan tangga.

Harris Hotel membuat aturan untuk tidak boleh merokok dalam kamar, bahkan tidak menyediakan smoking room. Hal tersebut adalah salah satu bentuk penghematan listrik, karena dengan adanya customer yang merokok dalam kamar, maka akan ada energi listrik yang perlu dikeluarkan untuk menghilangkan bau rokok tersebut dengan cara memvakum kamar. Dari beberapa hal tersebut dapat disimpulkan bahwa Harris Hotel \& Conventions Malang telah melakukan berbagai upaya untuk menggunakan dan mengelola energi se-efisien mungkin sekaligus ramah lingkungan. Harris juga berupaya mengajak karyawan dan customer nya untuk ikut berpartisipasi dalam gerakan green. Sebagai karyawan dan juga customer sama-sama memiliki peran dalam penghematan dan pengelolaan energi.

\section{Air}

Usaha dalam konservasi air bertujuan untuk menumbuhkan kesadaran akan pentingnya menghemat air dan sebuah langkah penghematan air untuk penggunaannya di bangunan (Kementerian Pariwisata Republik Indonesia, 2016). Hal ini disebabkan oleh ketergantungan terhadap sumber air bersih, seringkali tidak diiringi dengan perilaku yang mendukung yaitu menghemat air. Harris Hotel \& Conventions Malang belum maksimal dalam pelaksanaan program efisiensi air karena ketersediaan air yang berlimpah. Harris Hotel menggunakan $80 \%$ air tanah dan $20 \%$ air PDAM, Asisten Chief Engineer mengatakan bahwa Harris Hotel memiliki sumber air alami di area hotel sehingga Harris Hotel merasa ketersediaan air berlimpah bahkan lebih-lebih karena Malang cukup sering hujan. Meskipun demikian, Harris Hotel tetap berusaha memanfaatkan air sebaik mungkin, salah satu upayanya adalah dengan memasang sub-meter air untuk mengontrol penggunaan air. Harris Hotel juga membuat lubang-lubang biopori untuk resapan air hujan.

Sejauh ini Harris Hotel belum memanfaatkan air resapan dari biopori untuk dikelola kembali sebagai air siram tanaman atau lainya, karena alasan melimpahnya air yang 
dimiliki Harris Hotel. Terkait teknologi, Harris Hotel menggunakan peralatan air yang dapat menghemat penggunaan air seperti menggunakan Flush Tank, WC Flush Valve, dan Dual Flush Toilet yang hanya menampung dan mengeluarkan air kurang dari 6 liter per-flush. Namun sejauh ini Harris masih menggunakan kran wastafel yang diatur secara manual, belum menggunakan sensor. Hanya di bagian Kitchen yang sudah menggunakan kontrol otomatis dalam membuka keran di wastafel, sehingga dapat meminimalisir volume air yang terbuang, itu pun hanya sebagian wastafel saja.

Chief Engineer Harris Hotel menyampaikan bahwa Harris telah menggunakan teknologi STP untuk mengelola air limbah menjadi air yang layak pakai untuk menyiram taman, pendingin udara (cooling tower), dan flushing toilet. Namun untuk menyiram tanaman hanya dilakukan disaat musim kemarau saja. Sehingga dapat disimpulkan bahwa dari segi pemanfaatan air daur ulang di Harris Hotel \& Conventions Malang masih jauh dari maksimal. Meskipun demikian, Harris Hotel malang tetap berusaha memanfaatkan penggunaan air seefisien mungkin dan berusaha tidak mencemari lingkungan. Harris Hotel terus mengontrol kualitas dari air, baik yang bersih maupun dari hasil daur ulang. Secara berkala dilakukan pengukuran hasil uji kualitas air dari laboraturium secara mandiri (independent) dan sesuai dengan kriteria Peraturan Menteri Kesehatan No.416 Tahun 1990 tentang syarat-syarat dan pengawasan kualitas air.

4. Produk Ramah Lingkungan

Bangunan yang dikategorikan ramah terhadap lingkungan adalah bangunan yang terbentuk dari material ramah lingkungan saat menyusunnya (Kementerian Pariwisata Republik Indonesia, 2016). melihat karakteristik material yang digunakan sangat dikehendaki memiliki pendekatan ekologi pada rangkaian pembuatan, pengepakan, pengiriman hingga pemasangan. Termasuk didalamnya melihat spesifikasi detail unsur dan proses kimiawi (alami atau buatan) yang diperlukan untuk membantu membuat material bangunan. Harris telah menggunakan produk material bangunan yang ramah lingkungan seperti tidak menggunakan asbes, bahan yang mengandung merkuri, dan bahan berbahaya lainnya, Harris menggunakan produk material anti bakteri serta memiliki resistensi terhadap kontaminan. Hal tersebut telah sesuai dengan aturan yang ditetapkan oleh pemerintah. Dalam hal perawatan, menggunakan produk pembersih yang aman dan ramah lingkungan. Hal tersebut dijamin karena sudah mengikuti standar dan dikontrol rutin oleh pemerintah. Untuk produk yang dibeli mayoritas sudah menggunakan produk lokal. Sekitar $80 \%$ produk dan bahan makanan untuk restaurant menggunakan produk lokal dan hanya $20 \%$ yang import. Sudah ada upaya juga dari hotel untuk menerapkan sistem recycle dan reuse agar tidak banyak membuang bahan dan dimanfaatkan semaksimal mungkin. Selain itu, Harris Hotel telah berupaya memperbaharui produk yang digunakan agar menggunakan bahan-bahan yang lebih awet, tidak mudah rusak sehingga lebih ramah lingkungan dengan tidak sering menghasilkan sampah.

\section{Limbah}

Pengelolaan limbah menjadi sangat penting karena membantu pihak hotel untuk berusaha mengurangi beban limbah dengan membatasi pemakaian material yang berlebihan dan dapat memanfaatkan kembali limbah yang masih mempunyai nilai sehingga akan berdampak pada biaya yang akan dikeluarkan untuk mengelola limbah tersebut (Kementerian Pariwisata Republik Indonesia, 2016). Hotel yang akan dinilai sebagai Green Hotel harus dilengkapi fasilitas atau instalasi untuk mengelolah limbah padat dan limbah cair, sehingga hasil buangnya memenuhi standar baku mutu.

Harris Hotel \& Conventions Malang telah memiliki kebijakan dalam pengelolaan limbah hotel diantaranya Limbah Padat, Limbah Cair, dan Limbah B3. Pihak manajemen Harris Hotel Malang berupaya memanfaatkan kembali beberapa limbah salah satunya botol-botol bekas yang dijadikan vas bunga, dan handuk bekas yang dijadikan pot tanaman. Harris Hotel bekerjasama dengan vendor-vendor bank sampah yang bersertifikat resmi dari pemerintah untuk menjamin mutu pembuangan dari limbah-limbah yang dihasilkan oleh Harris Hotel. Biaya pembuangan untuk limbah B3 terbilang mahal, namun Harris Hotel tetap harus melakukannya sesuai ketentuan dari pemerintah agar tetap 
menjaga mutu dan nama dari Harris Hotel, selain itu agar tidak mendapat sanksi jika terjadi pelanggaran atau pencemaran yang terjadi akibat limbah dari Harris Hotel. Hal ini didukung oleh Holcomb, yang termasuk dalam orientasi dasar dalam green hotel yaitu adanya ketentuan dalam memilah sampah yang dapat didaur ulang seperti kertas dan majalah, botol kaca aluminium, botol besi, dan botol plastic, dan untuk bahan yang mengandung polusi seperti baterai dan kartrid, masing-masing bisa diambil dengan benar oleh perusahaan-perusahaan daur ulang dengan bidang khususnya masing-masing yang telah dikontrak oleh perusahaan (Holcomb, Upchurch, \& Okumus, 2007).

\section{Hambatan yang dihadapi Harris Hotel \& Conventions untuk menjadi Green Hotel}

Pertama, pihak owner belum memiliki keinginan untuk melabelkan Harris Hotel \& Conventions Malang sebagai Green Hotel. Akibat tidak ada pesaing hotel lainnya yang berlabel green di Malang, green hotel dirasa tidak mempengaruhi kunjungan customers. Hal tersebut sejalan dengan penelitian Sinangjoyo (2013), hasil wawancara dengan pihak manajemen yang sudah menerapkan green hotel menunjukan bahwa peran green hotel tidak begitu berpengaruh terhadap peningkatan tingkat hunian kamar (room occupancy).

Kedua, cukup sulit dalam menjaga konsistensi dalam menerapkan green hotel. Penyebabnya adalah tuntutan customer, sehingga terkadang akhirnya hotel harus mentolerir. Selain itu, sulitnya mengubah kebiasaan buruk dari karyawan atau customer yang belum biasa dan belum sadar untuk pentingnya kesadaran ramah lingkungan. Hal serupa didapati dalam Sinangjoyo, dari pihak manajemen hotel masih terdapat kurangnya sikap konsisten antara tingkat kesadaran terhadap praktek penerapannya (Sinangjoyo, 2013). Pada kenyataannya para staf hotel hanya sebatas menyadari namun praktek penerapannya dirasa masih kurang.

Ketiga, ketakutan pihak manajemen akan menurunnya kepuasan customers jika Harris Hotel \& Conventions Malang menerapkan konsep Green Hotel. HRM Harris Hotel \& Conventions Malang menyampaikan dalam wawancara bahwa tujuan utama Harris Hotel saat ini adalah guest satisfactions, sehingga dikhawatirkan jika Harris terlalu kaku menjalankan konsep Green Hotel akan membuat customer nya tidak kembali.

Keempat, HRM Harris Hotel \& Conventions Malang menyatakan terjadi kebimbangan ketika membuat kebijakan menghapuskan kamar-kamar yang smoking room dan menempel banyak poster larangan merokok. Bahkan Harris sempat tidak lagi menjual rokok untuk customers. Padahal Bentoel yang merupakan perusahaan rokok yang merupakan salah satu pelanggan VIP Harris Hotel \& Conventions Malang. Stiker No Smoking yang dipasang juga merupakan Peraturan Daerah Surabaya, bukan Perda Malang. Saat ini Harris Hotel \& Conventions Malang tetap menghilangkan kamar dengan tipe smoking room, dan tetap menempel banyak poster larangan merokok. Namun Harris tetap menjual rokok dan menyediakan smooking area di kawasan terbuka Harris Hotel.

Kelima, biaya yang tinggi untuk memaksimalkan konsep Green Hotel, misalnya untuk sistem STP, pembuangan limbah B3, mengganti banyak lampu menjadi LED, dan masih banyak lainnya. Dari penelitian Sinangjoyo juga didapati bahwa biaya untuk mengkonsumsi green product justru dirasa lebih mahal dan pihak tamu merasa masih dibebani dengan biaya konservasi serta CSR (Sinangjoyo, 2013).

\section{Hal positif yang didapatkan Harris Hotel \& Conventions dengan menjalankan konsep Green Hotel (konsep ramah lingkungan)}

Dengan menjalankan konsep Green Hotel, terdapat beberapa hal positif yang dirasakan oleh Harris Hotel \& Conventions Malang. Pertama, pihak manajemen Harris Hotel merasa bahwa dari beberapa biaya menjadi lebih hemat (saving cost). Kedua, HRM Harris Hotel \& Conventions Malang menyatakan dalam wawancara bahwa ada respon positif yang diterima oleh hotel dengan diterapkannya konsep Green Hotel. Dalam penelitian Chen dan Chen, didapati bahwa manajer hotel mengindikasi dengan menjalankan green hotel tidak hanya sangat mengedukasi konsumen, namun juga dapat menghemat banyak energi, dapat memperbaiki hotel dan seluruh lingkungan sosial (Chen \& Chen, 2012). 
Reaksi customers terhadap gerakan Green Hotel yang diterapkan Harris Hotel \& Convention

Dari 15 informan yang diwawancarai, terdapat 4 customer yang benar-benar mengetahui konsep Green Hotel, 7 customer pernah dengar, tahu, namun tidak begitu mendalam memahami konsep Green Hotel dan 4 customer menjawab belum atau tidak tahu. Selain melakukan penelitian, peneliti juga berusaha sekaligus mengedukasi dan mengenalkan konsep Green Hotel bagi para customer yang belum mengetahui konsep tersebut. Para informan yang diwawancarai menyatakan bahwa mereka belum tahu bahwa Harris sudah Green Hotel, hanya merasakan bahwa sepertinya sudah mengarah ke Green Hotel. Hal tersebut sesuai dengan hasil wawancara dengan pihak manajemen bahwa Harris Hotel \& Conventions Malang memang belum melabelkan hotelnya sebagai Green Hotel.

Peneliti pun menanyakan kepada kelima belas customer yang menjadi informan dalam penelitian ini akan setuju atau tidaknya mereka jika Harris Hotel \& Conventions Malang menerapkan dan menjadi Green Hotel. Kelima belas customer menjawab setuju dan mendukung.

Harris Hotel \& Conventions Malang telah berusaha melakukan campaign dengan menggantungkannya di rak handuk setiap kamar mandi hotel. Gantungan tersebut bertuliskan ajakan untuk turut serta menjaga lingkungan dengan latihan green behaviour, diantaranya mematikan semua lampu dan AC saat meninggalkan ruangan, menggunakan handuk kembali setelah digunakan dengan menggantungkannya di rak handuk, dan berkenan mengganti sprei setiap 2 hari sekali. Gantungan tersebut merupakan alat pemasaran green sebagai sarana memudahkan konsumen mempersepsikan dan memunculkan kesadaran akan produk green (Setiyaningrum, Udaya, \& Efendi, 2015). Tujuannya untuk merubah perilaku pembelian konsumen dari yang awalnya membeli produk konvensional, jadi beralih membeli produk ramah lingkungan untuk mengurangi dampak negative pada lingkungan. Ternyata hasil penelitian ini menemukan bahwa tidak semua customer melihat dan membaca campaign pada gantungan tersebut. Dari 15 customer yang diwawancarai, 5 customer tidak melihat ada gantungan ajakan green behaviour dari hotel, 2 customer melihat tapi tidak membacanya, dan 8 customer melihat dan membaca tulisan di gantungan tersebut.

Peneliti membuat beberapa poin untuk mengetahui selama ini sejauh mana customer melakukan gerakan yang termasuk dalam Green Hotel. Ditemukan bahwa semua informan selama menginap dihotel telah menyalakan lampu sesuai kebutuhan, mematikan tv atau setidaknya memasang timer saat tidur, dan menggunakan air panas dengan bijak. 1 informan meminta sprei diganti setiap hari dan 14 informan tidak keberatan bila sprei tidak diganti setiap hari atau diganti tiap dua hari sekali. 14 dari 15 informan mematikan air saat tidak digunakan, dan 1 informan tidak demikian. Dari 15 informan hanya 1 yang terkadang tidak membuang sampah pada tempatnya, dan 14 informan lainnya membuang sampah pada tempatnya. 12 dari 15 informan tidak merokok dalam kamar atau di toilet, dan terdapat 3 informan yang sulit untuk tidak melakukannya. Untuk tidak mengganti handuk setiap hari, tidak semuanya bersedia. Didapati dalam penelitian ini bahwa dari 15 customer yang menjadi informan, 9 orang tidak masalah bila menggunakan handuknya kembali, 2 orang terkadang minta diganti jika kotor atau terlalu basah, dan 4 orang lainnya meminta handuk untuk diganti setiap hari. Mereka merasa bahwa sudah mengeluarkan biaya yang cukup mahal untuk menginap dihotel tersebut untuk mendapatkan pelayanan yang sepadan. Sejalan dengan hasil penelitian Lee, Jai, and Li yang menunjukkan bahwa sebagian tamu merespon positif terhadap praktik green ketika mereka memahami pentingnya menjaga lingkungan, mereka berkenan mengurangi penggunaan energi atau penghematan air, namun terdapat sebagian tamu lainnya yang merasa tidak nyaman selama masa inap mereka karena kurangnya pemahaman tentang praktik Green Hotel (Lee, Jai, \& Li, 2016). Hal ini ditunjukkan dengan sikap tamu yang tidak menghendaki adanya pembatasan fasilitas, pembatasan sumber daya, penentuan area dan sistem larangan (Sinangjoyo, 2013).

Peneliti menanyakan pada 15 informan untuk mengetahui pendapat mereka jika harga hotel menjadi lebih mahal agar bisa menjadi Green Hotel. Dalam penelitian ini didapati bahwa, 11 informan tidak keberatan dan 4 informan keberatan. Para tamu hotel yang sadar akan pentingnya ramah lingkungan cenderung 
bersedia membayar dengan harga yang lebih mahal untuk menginap dihotel tersebut karena mereka sadar bahwa produk hijau memang lebih mahal dari pada produk-produk yang tidak ramah lingkungan (Desliana, Gaffar, \& Andari, 2014). Meski demikian, hotel bisa saja tidak menaikkan harganya jika melakukan riset pada pasar terlebih dahulu, atau mereka akan kehilangan bisnis dan pelanggannya (Chan, 2013).

Terdapat beberapa harapan dari beberapa informan untuk Harris Hotel \& Conventions Malang untuk dapat mengoptimalkan konsep Green Hotel. Diharapkan dapat meningkatkan dalam mengenalkan Green Hotel pada customer dengan cara memperbanyak tagline ajakan Green di area hotel. Dengan Harris Hotel \& Conventions Malang berani menjadi Green Hotel pertama, diharapkan mampu mengajak hotel lainnya dan para customer untuk turut serta. Minat customer yang biasa saja terhadap hotel-hotel yang ramah lingkungan atau Green Hotel diakibatkan oleh berbagai faktor, salah satunya adalah mereka merasa sangat kesulitan dalam mendapatkan informasi seputar hotel-hotel yang menerapkan konsep Green Hotel (Ferianto, Darsiharjo, \& Rahmafitria, 2014). Green hotel masih dipandang asing oleh wisatawan sehingga berpengaruh terhadap kepedulian mereka terhadap hotel yang ramah lingkungan atau tidak.

\section{KESIMPULAN DAN SARAN Kesimpulan}

Harris Hotel \& Conventions Malang sudah menjalankan sebagian besar konsep Green Hotel sesuai dengan ketentuan Kementrian Pariwisata Republik Indonesia, mulai dari desain bangunan dan material yang digunakan, efisiensi energi, air, pemilihan produk yang digunakan dan dalam pengelolaan limbah sudah dijalankan meskipun belum 100\%. Alasan Harris menjalankan Green Hotel yang pertama karena ada aturan dari pemerintah terkait Perlindungan dan Pengelolaan Lingkungan Hidup, sehingga untuk menjaga nama Harris Hotel dilakukanlah sesuai ketentuan-ketentuan dari pemerintah. Kedua, Tauzia manajemen ingin menjalankan prinsip pengelolaan lingkungan berkelanjutan demi menjaga kelestarian dan keseimbangan ekologi bagi kehidupan makhluk hidup selanjutnya.
Harris Hotel \& Conventions Malang mebuat kebijakan dari segi bangunan, efisiensi energi, pemilihan produk, dan pengelolaan limbah telah memenuhi standar konsep Green Hotel. Tetapi untuk kebijakan dalam efisiensi air.belum maksimal. Pihak Harris merasa bahwa hotel tersebut memiliki air yang berlimpah karena memiliki sumber air dan Malang cenderung sering hujan, sehingga belum ada kebijakan dalam pemanfaatan kembali dari air daur ulang. Jika diperlukan, air daur ulang digunakan untuk menyiram tanaman hanya dilakukan saat musim kemarau. Meskipun demikian, Harris tetap berusaha memanfaatkan penggunaan air seefisien mungkin dan berusaha tidak mencemari lingkungan.

Beberapa hambatan yang dihadapi Harris Hotel \& Conventions Malang dalam menerapkan Konsep Green Hotel (1) Owner belum memiliki target untuk melabelkan Harris Hotel \& Conventions Malang sebagai Green Hotel. (2) Cukup sulit untuk menjaga konsistensi menjalankan kebijakan Green Hotel. (3) Ketakutan pihak manajemen akan menurunnya kepuasan customers. (4) Terjadi kebimbangan ketika membuat kebijakan menghapuskan kamarkamar smoking room dan menempel banyak poster larangan merokok, sementara salah satu pelanggan VIP Harris Hotel \& Conventions Malang adalah perusahaan rokok. (5) dibutuhkan biaya yang tinggi untuk memaksimalkan konsep Green Hotel.

Hal positif juga dirasakan oleh Harris Hotel \& Conventions Malang setelah menjalankan konsep Green Hotel. Dengan adanya teknologi terbarukan membuat beberapa biaya menjadi lebih hemat (bisa saving cost untuk biaya listrik, tidak lagi membeli solar dan LPG). Terdapat respon positif yang diterima oleh hotel walaupun customer yang belum tau soal green cenderung menilai dari segi general atas apa yang mereka rasakan, tapi tidak dapat dipungkiri bahwa respon positif yang mereka rasakan adalah dampak dari konsep Green Hotel.

Respon dari para customer Harris Hotel \& Conventions Malang cenderung mendukung jika Harris menjalankan konsep Green Hotel. Sejauh ini campaign yang dilakukan oleh Harris Hotel kurang maksimal karena banyak customer yang tidak mengetahui dan tidak menyadari adanya ajakan dari Harris Hotel untuk turut serta 
dalam gerakan Green Hotel. Dalam penelitian ini ditemukan bahwa customer cenderung bersedia untuk menghemat penggunaan listrik dan air, mengganti sprei setiap 2 hari, namun tidak semua bersedia untuk tidak mengganti handuk setiap hari. Bagi yang memahami tujuan dibuatnya konsep Green Hotel dan sadar akan pentingnya ramah lingkungan, mereka bersedia membayar lebih mahal asal benar-benar digunakan untuk membangun lingkungan yang berkelanjutan. Bagi customer yang belum begitu memahami tujuan dari konsep tersebut cenderung keberatan jika harga hotel menjadi lebih mahal. Harapan mereka adalah Harris Hotel dapat meningkatkan dalam mengenalkan Green Hotel pada customer dengan cara memperbanyak tagline ajakan Green di area hotel. Dengan Harris Hotel \& Conventions Malang berani menjadi yang pertama menjadi Green Hotel, diharapkan mampu mengajak hotel lainnya dan para customer untuk turut serta.

\section{Saran}

Hasil penelitian ini masih bisa dikembangkan, baik secara kualitatif maupun kuantitatif. Penelitian yang akan datang diharapkan dapat mengembangkan konseptual dan permodelan kajian ini pada objek-objek kajian penelitian yang lebih luas agar diperoleh perbandingan dan pengetahuan lebih terkait Green Hotel. Untuk memaksimalkan program Green Hotel dibutuhkan kerjasama tidak hanya dari sektor perhotelan, namun juga dari pemerintah untuk mensosialisasikan pada masyarakat agar banyak yang akan tahu dan familiar dengan program pembangunan lingkungan berkelanjutan. Pemerintah harus berusaha lebih keras untuk mempromosikan ide perlindungan lingkungan, agar meningkatkan kesediaan masyarakat untuk memilih Green Hotel dapat meningkat. Hal tersebut juga akan membuat hotel mempercepat untuk menjadi Green Hotel melalui kekuatan konsumen (Chen \& Chen, 2012).

Dari hasil penelitian ini didapati bahwa hampir dari semua customer yang diwawancarai mendukung jika Hotel menjalankan gerakan ramah lingkungan dengan konsep Green Hotel, sehingga bisa menjadi pertimbangan bagi para pelaku hotel untuk menerapkan konsep Green Hotel pada hotelnya. Lingkup yang diteliti dalam penelitian ini masih terbilang kecil sehingga penelitian mendatang bisa lebih meluaskan dan mengembangkan lagi dalam meneliti penerapan konsep Green Hotel.

\section{DAFTAR PUSTAKA}

Anggita, D., Wardhani, A., \& Danusastro, Y. (2016). Penilaian Aspek Green Hotel Kelas menengah (Hotel Berbintang 1,2,3. Modul, Vol.16 No.1.

Arjana, I. G. (2016). Geografi Pariwisata dan Ekonomi Kreatif. Jakarta: Rajawali Pers.

Badan Pusat Statistik Kota Malang. (2017). Kota Malang Dalam Angka 2017. Malang: BPS Kota Malang.

Chan, E. S. (2013). Gap analysis of green hotel marketing. International Journal of Contemporary Hospitality Management, Vo.25 No.7.

Chen, Y.-C., \& Chen, Y.-T. (2012). The Advantages of Green Management for Hotel Competitiveness in Taiwan: In the Viewpoint of Senior Hotel Managers. Journal of Management and Sustainability, Vol.2 No.2.

Desliana, A., Gaffar, V., \& Andari, R. (2014). Pengaruh Program Green Marketing di Hotel Shangri-la Jakarta terhadap Green Consumer Behavior. Tourism and Hospitality Essentials (THE) Journal, Vol.4 No.1.

Erdogan, N., \& Baris, E. (2007). Environmental Protection Programs and Conservation Practices Of Hotels in Ankara, Turkey. Tourism Management, Vol.28 Iss.2 pp 604-614.

Ferianto, A. R., Darsiharjo, \& Rahmafitria, F. (2014). Pengaruh Konsep Green Hotel terhadap Minat Berkunjung Wisatawan ke Kota Bandung. Antologi Management Resort \& Leisure, Vol.2 No.2.

Holcomb, J. L., Upchurch, R. S., \& Okumus, F. (2007). Corporate Social Responsibility: What Are Top Hotel Companies Reporting? International Journal of Contemporary Hospitality Management, Vol.19 No.6 pp 461-475. 
Kabar Bisnis. (2010). Wisata MICE Harus Terapkan Green Tourism. Retrieved 03 12, 2019, from Kabar Bisnis: https://kabarbisnis.com/read/2810335/wi sata-mice-harus-terapkan-i-greentourism-i-

Kementerian Pariwisata Republik Indonesia. (2016). Panduan dan Pedoman Pelaksanaan Green Hotel Indonesia. Jakarta: Wonderful Indonesia.

Lee, H., Jai, T.-M. (., \& Li, X. (2016). Guests Perceptions of Green Hotel Practices and Management Responses on TripAdvisor. Journal of Hospitality and Tourism Technology, Vol.7 No.2.

McDaniel, S. W., \& Rylander, D. H. (1993). Strategic Green Marketing. Journal of Consumer Marketing, Vol.10 No.3.

Nitisusastro, H. M. (2013). Perilaku Konsumen: Dalam Perspektif Kewirausahaan. Bandung: Alfabeta.

Polonsky, M. J. (1994). An Introduction to Green Marketing. Electronic Green Journal, Vol.1 No.2.
Robinot, E., \& Giannelloni, L. (2010). Do Hotels Green Attributes Contribute to Customer Satisfaction. Journal of Services Marketing, Vol.24 No.2.

Schiffman, L., \& Kanuk, L. L. (2008). Perilaku Konsumen. Edisi Ketujuh. Alih Bahasa: Drs.Zoelkifli Kasip. Indonesia: PT. Indeks.

Setiyaningrum, A., Udaya, J., \& Efendi. (2015). Prinsip-Prinsip Pemasaran

Pengenalan Plus Tren Terkini Tentang Pemasaran Global, Pemasaran Jasa, Green Marketing, Entrepreneural Marketing dan E-Marketing. Ed 1. Yogyakarta: ANDI.

Sinangjoyo, N. J. (2013). Green Hotel sebagai Daya Saing Suatu Destinasi. Jurnal Nasional Pariwisata, Vol. 5.

Wu, S.-I., \& Chen, Y.-J. (2014). The Impact of Green Marketing and Perceived Innovation on Purchase Intention for Green Products. International Journal of Marketing Studies, Vol.6. 